\title{
SEXUAL VIOLENCE AGAINST WOMEN IN NIGERIA AND VICTIMS' SUSCEPTIBILITY TO PSYCHOLOGICAL DISTRESS AND SEXUAL DYSFUNCTION
}

\author{
${ }^{* 1}$ Labe, R. M., ${ }^{2}$ Amande, A. M., ${ }^{3}$ Terngu, T. P., \& ${ }^{4}$ Atsehe, A. P.
}

\author{
${ }^{* 1}$ Department of Clinical Psychology, Federal Medical Centre Makurdi, Benue State \\ ${ }^{2}$ Department of Geography, Benue State University Makurd, Nigeriai \\ ${ }^{3}$ Department of Educational Psychology, College of Education Katsina-Ala Benue State, Nigeria \\ ${ }^{4}$ Department of Psychology Benue State University, Makurdi, Benue State, Nigeria \\ *Corresponding Author Email: laberansome@gmail.com
}

\begin{abstract}
The purpose of this paper was to present a comprehensive review of sexual violence against women and the victims' susceptibility to emotional distress and sexual dysfunction. A total of 50 cases of rape victims and rape statistics report were gathered from secondary sources of information. From the retrospective description of some victims' traumatic experiences, the picture of their negative emotions and grief were carefully analyzed and explanation provided on their exposure to psychological distress and psychosexual dysfunction. Deducing from the review and analysis of the histories and experiences of sexual violence victims, there is a strong relationship between women with history of sexual violence and susceptible to psychological distress sexual dysfunction such as; PTSD, sexual arousal inhibition, sexual avoidance contact, anger and hatred. Others include paranoia, fear of relationship with men as well as stress and reexperience of grief from the unpleasant memories of the rape incidence. Pathologically, sexual violence can threaten the psychological well-being of the survivors in a short and long-term depending on the circumstances and probably where the victim is left without care and support from friends, family and appropriate professional intervention. Thus, women who have been exposed to rape need intensive and suitable psychological intervention to heal their traumatized emotions that induce psychological distress and sexual dysfunction.
\end{abstract}

Keywords: Psychosocial distress, Rape, Women, Sexual violence, Victims'susceptibility, Sexual-dysfunction

LICENSE: This work by Open Journals Nigeria is licensed and published under the Creative Commons Attribution License 4.0 International License, which permits unrestricted use, distribution, and reproduction in any medium, provided this article is duly cited.

COPYRIGHT: The Author(s) completely retain the copyright of this published article.

OPEN ACCESS: The Author(s) approves that this article remains permanently online in the open access (OA) mode.

QA: This Article is published in line with "COPE (Committee on Publication Ethics) and PIE (Publication Integrity \& Ethics)". 


\section{INTRODUCTION}

It has been understood and known that change is a constant process - in life until death occurs (emphasis added). Fundamentally, different times, situations and events are stimulus to change in human behaviour, which could be positive or negative. Taking this view into account, there is a clear distinction between observed peoples' social behaviour four decades ago. Comparatively, there were no or inconsequential incidences or reports of deviant social behaviours exhibited by the young and old adults in the previous century than the latter. Generally, good social moral values and norms were consciously observed and preserved through self-discipline, self-control, love and respect for one another in a community. The male and female interpersonal relationship had defined approaches and rules of engagement for purpose of sexual relationship or marriage. The process of seeking and initiating a relationship with a girl or woman was characterized by a friendly and humble approach to win her admiration and acceptance for engagement in relationship. Premarital sex was absolutely abhorred and chastised and it served as a guide against sexual indulgence and exploitation. Consequently, there were scarcely incidences of sexual violence against women in the communities for fear of the aftermath against the perpetrator of the act. Contrary to the well imbibed standard moral and good social behaviours and attitudes that characterized the traditional society before the $21^{\text {st }}$ century, there is a marked deregulation of self-control and discipline concerning sexuality. Men are engrossed in an aggressive quest for sexual exploitation and violation of women sexual right and dignity (Ricardo \& Barker, 2008; Smuts, 1992). This occurs in various forms of prohibited sexual acts such as rape, paedophilia, incest and sexual harassment or abuse.

Evidently, there were these anomalous sexual behaviours known and perpetrated by some people in early civilized societies up to date. However, the stories heard about these sexual behaviours from these societies were regarded as weird and repugnant. Unfortunately, these same recognized repulsive sexual behaviours have crept into traditional African societies including Nigeria. Hardly, does a day go by without a reported incidence of a sexual violent act particularly rape and other sexual offences. Perhaps, this disturbing and uncontrollable prevalence of sexual violence in the country today has evolved from a dynamic influence of interrelated factors such as; erosion of social and moral values, unemployment, poverty, drugs/substance abuse, unresolved intrapsychic conflicts, low self-esteem, broken marriages, widowhood/sexual insecurity, and many others not mentioned. Sexual violence is a serious public health and human right problem with short-and-long term consequences on the woman physical, psychological, social, sexual and reproductive health (Campbell, 2008).

\section{LITERATURE REVIEW}

The World Health Organization (WHO) defined sexual violence as any coerced sexual act, involving: any sexual attempt of sexual act, sexual comments, or act directed against a person' sexuality using force, by any person regardless of his relationship to the victim in any setting including home and work. This definition involves rape which is the "penetration, no matter how slight, the vagina or anus with any body part or object, or oral penetration by a sex organ of another person, without the consent of the victim" (Carbon, 2012). Essentially, this definition includes any gender of victim and perpetrator, and not just the women. It also recognizes that rape with an object can be as traumatic as penile/vagina rape. The definition also includes instances in which the victim is unable to give consent because of temporary or permanent mental or physical incapacity (Carbon, 2012). A rape can be perpetrated by a single person 
or by two or more persons (gang rape). Often times, rapist can rape a target victim trapped in his or her house, solitary places and on a deserted road or path in a very degrading and frightening manner. The News Agency of Nigeria (NAN) confirmed from the Public Relation Officer of the Kano State Police Command that 33.3\% of cases of rape were in uncompleted building (Punchonline newspaper, 2020). Disturbingly, these growing incidences of rape are occurring in all the States across Nigeria and this has ignited series of serious public concern and protest. Daily reports of incidence of rape around the country exposed bizarre cases of sexual violence of the most monstrous types against young, old women and children. Unfortunately, the teenage girls and female children are the most targeted

Besides and sadly, there are irritating cases of fathers forcibly having sex with their daughters who are legally recognized as minors. The father's sex intercourse with his daughter is incest which is another sexual crime defined for people having intercourse with blood tied family members. It is traditionally and legally prohibited. For example, among Tiv people there are clear incest taboos that set boundaries within sexual relationship were allowed or sanctioned... sanctioned ranging from the ritual of burning to stigmatization (All Answer, 2018). For example, in some communities like where (my mother is from), two blood tie family members like a brother and sister found having sexual intercourse - unless a rite of cleansing and severance of the two from their family tie is performed, they will be barren and never have good fortune in life. Incest is recognized as a taboo in almost all ethnic groups and it is by law prohibited in Nigeria. Unfortunately, this sexual act has become rampant and perpetuated by fathers, uncles and child guardians. A review of available information in newspapers, police arrest, government ministries, agencies and NGOs show that men have dominated the perpetration of sexual violence. The most recent and gruesome rape incidence obtained from the newspaper reports and other secondary sources narration of single and gang rape incidence are as follows.

A 22-year-old Vera Uwaila Omezuwa, a first-year microbiology student was raped and brutally murdered in a church in Benin City. An 18-year-old student of Federal College of Animal and Production Technology was raped and dumped dead in a pool of blood in Ibadan. A man rapes 14-year-old girl in Kogi and threatens to kill family member (Queen Moomoo, 2020). A Commissioner for Water Resources in Kogi State was suspended for battering and raping of a beauty queen. Police in Anambra State have arrested 32-year-old man for defiling a seven-year-old girl. In Zamfara state, police arrested a 25years old man for raping and killing his half-brother's wife. A 70-year-old woman was overpowered and raped by a 25 -year-old truck driver. In Benue State, a House of Representative member and One Idoma Initiative has placed a bounty of $\$ 150,000$ on a chieftain of the All-Progressive Grand Alliance Party (APGA) who went into hiding for allegedly raping a 15-year-old girl. A 26years old man escaped death from angry mob for raping a six years old girl on the premises of a worship centre in Makurdi (Punchonline newspaper, 2020). Eight rape cases were reported in Otukpo, Benue State in the month of June, 2020 (TVC News Channel). In a conversation, Ann Ameh a Superintendent of Police and the head of gender unit criminal investigation department (CID) Benue state Police command disclosed that they have handled approximately 36 cases of rape from January to July 2020.

A 35-year-old man was arraigned before a magistrate court for raping a physically challenged girl in Ogun state. In Akwa-Ibom State, a 38years old cultist was arrested for luring to the hotel 14-year-old girl and raping her. Ogun State police command has arrested a 25-year-old man for raping of a 20-year-old girl with Down's syndrome 
(Olatunji, 2020). While in Bauchi state a 28 -year-old man was caught for defiling eight minors aged between four and eight, six- and four-months old babies were raped (Punchonline newspaper, 2020). A 40-year-old was caught in Nasarawa state for raping a three months old baby. Police arrest bishop for raping a 19-year-old girl in Delta State (Mandehin, 2020). A pastor was arrested for purportedly raping a 16-year-old girl (Mandehin, 2020). Some of the gang rape cases recently reported shows police arrest of two teenagers for gang raping a 15-year-old girl (Mandehin, 2020). An 11-year-old was raped by eleven men in Jigawa state (Vanguard, 2020). The Kaduna State Ministry of Human Services and Social Development have launched an investigation in a case of a 13-year-old girl who was drugged and gang raped by four men. A 12-year-old girl is experiencing trauma after she was gang raped by four masked men in Lagos. Besides, a secondary school pupil was found where she was raped and left bleeding from injuries in vagina also in Lagos. A 29-year-old girl was gang raped by eight men in Akoko-Edo. Another victim ran away from her home after she was raped twice in a week by some suspected cult members in Ikpba-Okha in Edo state (Punchonline newspaper, 2020). In another incidence, three-armed men gang raped a 17-year-old street hawker at Oja-Oba market in Ekiti State (Punchonline newspaper, 2020).

On memory recall of rape experience, Sylvia living with a hurting memory narrated a story of how she was gang raped by six men in her 100 level in Imo State University (Puncholine newspaper, 2020). Another 24-year-old Victoria told a tale of how she was sexually assaulted by a gang of hoodlum on her way back from the church. She recalled:

\author{
"I was taken to an uncompleted building and was sexually molested by two \\ of the four gang men. Their leader slapped me and as I fell to the ground in \\ tears, he warned me that if I said anything else, he was going to cut my \\ throat and leave my body to rot there. He forced himself in me and passed \\ me to the next person before they ran off."
}

A Nigerian table tennis player bewails "I have been abused and after beating me, he will forcefully have sex with me. It is when I grew up, I got to know that it is called rape". As a result, she states that she has developed hatred for sex after she was raped as a young girl (Punchonline newspaper, 2020). In-so-much-as these incidences of rape would be perceived as horrific sexual violence, it would disgust anyone to read reports about anomalous sexual behaviours like incest and paedophilia perpetrated today by some parents and men in Nigeria. It is unsettling to recognize that in this modern era of proliferative religiosity, which is expected to regulate misconduct, and promote assimilation of good moral and social values, is rather seen to be eclipsed by perverted and maladaptive behaviours in the society. Strange as it may seem, incest is been perpetrated by fathers and uncles without guilt and regret. There are numerous cases where fathers have forcibly violated their own daughter's sexual receptivity even when they are minors. In most cases, fathers who raped their daughters threaten to kill them if they tell anybody about it.

For example, Peace states that she was defiled by her father at nine years and threatened to kill her if she tells anybody about it. Similarly, a lady identified as Rachael lamented that "I still live with the scar till today" as she revealed that she was raped by her father. Sophia disclosed that she was raped by her uncle who was living with her 
family. After the incident, she added; "I was traumatized and scared of men. I use to fill with disgust, sometimes I felt nauseous and later to have nightmares". Some victims of rape honestly disclosed that they are yet to heal from the grief of their untold trauma due to the horrible experience (Punchonline newspaper, 2020). Furthermore, a 35-year-old man was arrested for impregnating his stepdaughter. The memories of October, 2018 public outcry in Benue state about the death of 13-year-old Elizabeth Ogbaje after she was repeatedly raped for five years by her uncle and his son would never be forgotten soon. Additionally, a 36-year-old father defiled his one-year-old daughter in Lagos. 35-year-old father defiled his 12-year-old biological daughter. Court jailed a 40-year-old man for raping his 17-year-old daughter in Edo state (Vanguard newspaper, 2020). A 44-year-old pastor of the Christ Apostolic Church raped and impregnated his daughter three times and took her for abortion for all (Punch newspaper, 2020).

Samuel Emeka was arrested for defiling and having repeated sex with his 7 months old baby girl in Makurdi. In Niger State, a man revealed that he has been having sex with his two daughters for close to ten years. Besides, a 70year-old man raped an 8-year-old girl and gave her 80 naira to silence her from telling anybody about it. In Ikorodu, Lagos State, a father 61 years old was arrested for having sexual intercourse with his 19-year-old daughter without her consent. The victim revealed that her father started having sex with her when she was young and he always threatened to deal with her if she tells anybody about it. Similarly, a 33-year-old man was caught for defiling his 14-year-old daughter in Bariga area also in Lagos. On the opposite, a practical Oedipus complex behaviour was displayed in an incidence where a 27-year-old man forcibly had intercourse with his own mother in Ado-Ekiti (Punch newspaper, 2020). Another rape victim identified as Grace recalled with tears how she was raped by 55-year-old uncle she was staying with when she was to sit for her West African Senior School Certificate Examination (WASSCE) in Uyo, Akwa-Ibom state. A 30-year-old woman narrated that she was kidnapped and taken to a dense forest where she was raped every day until a ransome was paid before she was released by her captors (Agiriga, 2019). A 26-year-old man was caught for defiling an eight years old school pupil in his residence at Ikwere local government area of Rivers state. Gunmen attacked a hotel in Awka North of Anambra state and raped two female guests. In Imo state, a 26-year-old employee had confessed to having sexual intercourse with his employer's 10years old twin daughters since 2019 (Moomoo, 2020). Victoria painted a horrible story of how she was abducted by Fulani herdsmen, raped in turns and offered human blood as drinking water (Odita, 2020). Chioma a 20-year-old girl rescued by the police narrated that she was abducted with his brother and taken into the forest, raped repeatedly by five men, while others inserted objects into her vagina. Thereafter, they beat and forced her brother to have sex with her and he had no option than to do so for fear of their threat to kill him (Nnachi, 2020).

Statistically, rape cases and other bizarre sexual violent behaviours expressed by men are underreported resulting to lack of comprehensive data availability about these illegal sexual activities in the country. Probably this is so because of the recognition of the undignified and negative social consequences and other reasons associated with it. Despite this fact, available statistics indicate that there is an unprecedented increase in the incidence of sexual violence in the Nigerian communities. Nigeria Inspector General of Police revealed that 717 rape cases were reported from January to June, 2020 (Punchonline newspaper, 2020; TVC News, 2020). More than 80 rape cases were reported in various parts of Anambra state during the covid-19 lockdown order between April and May. In Akwa-Ibom state, there are 100 cases of rape that were received at the Ministry of Justice (Punchonline newspaper, 2020). The Kano 
State police command recorded 47 rape cases between January and May. Besides, on the $13^{\text {th }}$ of July, 2020, the Minister of Women Affairs and Social Development announced that 3,600 cases of rape were received during the lockdown period. She explained that commissioners of women affairs across the 36 states in Nigeria reported each state recorded up to 100 cases during the lockdown (Punchonline, 2020).

Looking backward, in 2016 the National Bureau of Statistics (NBS) reports that 45,554 cases of offences like murder, infanticide, rape and others were committed against persons. While 2279 cases of rape and indecent assault in 2017 was recorded. Barrister Zainab Aminu Garba, the chairperson of the International Federation of Women Lawyers observed that rape becoming an epidemic in the North-western Nigeria (Agiriga, 2019). In 2018, the Women at Risk Foundation (WARIF) reports that over 10000 girls were being raped in daily in Nigeria. In 2019, Pauline Tallen, the Minister of Women Affair and Social Development estimated that two million Nigerian women and girls were sexually assaulted annually. According to a report released in Abuja, the Northwest has $92 \%$ to emerge as the environment with highest prevalence of rape followed by Southwest Nigeria with 91\% of cases (Jannamike, 2019).

Relatedly, Africa Unite an arm of the United Nation Women campaign against gender-based violence in 2019 indicates that $45 \%$ of women in sub-Saharan Africa experience sexual assault by a person they might be familiar with at one time in life. Basically, from the official records alone it is obvious that rape is rampant, but then data on sexual violence cases remain very limited. Unfortunately, even with recognition of rape and other abnormal sexual behaviour expressed by men against women as a serious crime; "these cases are seemingly downplayed when they are reported to the police and other allied law enforcement agents" (A Ameh personal communication, July 11, 2020). Besides, parental greed and political interference contribute to weaken or block the procedure of the law to punish perpetrators of the act. Consequently, those that commit it continue the act which goes to encourage others to think they are also at liberty to go out and violate the women, girls and babies' sexual rights and dignity. Perhaps, it is convinient to allude that the frequent incidence of sexual violence against women is driven by men's conscious or unconscious desire to promote gender inequality, perceived weak legal enforcement mechanism, and women weak self-defense. In fact, these factors contribute to the manner in which rape cases are treated with levity and leave the victim with traumatizing memories and pains.

\section{METHODOLOGY}

\section{RESEARCH DESIGN}

This study adopted a qualitative research approach with focus to review and analyze and describe the uncontrolled phenomenon of sexual violence against women in Nigeria and the victims' susceptibility to psychological distress and sexual dysfunction. Consequently, a secondary research method which is a type of exploratory design was employed for the purpose of gathering and reviewing information on sexual violence incidences in Nigeria. The information was primarily gathered mostly from the electronic and print media sources such as newspaper, television news, Facebook post and blogger's news headlines, and rape stories for a comprehensive presentation and description of cases and how the traumatic experience of the rape exposes victims to psychological distress and sexual dysfunction in their later life.

\section{SAMPLE/POPULATION FOR THE STUDY}


The population of the study was victims of sexual violence in Nigeria. They were of course not contacted physically to elicit information on their experiences after the rape incidence. The sample of the cases reviewed comprised of rape victims whose stories were obtained from reported stories in the electronic and print media sources in Nigeria. The sampled cases predominantly consisted of female sex group which include the old, young girls and female infants who were exposed to the brutal force of rape perpetrated by old and young male adults in different rural and urban communities across the states. A total of 50 women cases of rape victims were gathered and reviewed.

\section{DATA COLLECTION}

The information on the incidence of sexual violence against women represented in the study was obtained from secondary sources. Some of this information was collected from the daily reported cases of rape occurring in the different communities of the states in Nigeria by Punch and Vanguard newspapers. Some were derived from television and Facebook post and bloggers' news headlines, online researcher publications, government agencies and NGOs statistics reports. The data derived for the purpose of the review for the paper began from January to August, 2020.

\section{DISCUSSION}

The study objective was to review and describe the prevalence of sexual violence against women, the victims' susceptibility to mental and sexual dysfunction. Sexual violence, rape in particular against girls and women is a sad reality in Nigeria (Tade \& Ugochukwu, 2020). In recent times, this weird and hideous sexual violence, especially rape of women by some old and young men has aroused a miffed concern which has provoked serious public protest in Nigeria. Mind-boggling is the fact that some cases of rape take place with the murder of the victim. Rape is a violent sexual act that has potential traumatic effect that often paralyzes the victim physically and emotionally as the woman does not always have any thought to expect or prepare for any sudden violation of her sexual right by a stranger or familiar person.

Extrapolating, from the analysis of victim's experience of sexual violence, women exposed to sexual violence irrespective of their age are frequently physically and psychologically hurt from the experience of induced protracted emotional disorder if not treated as it was established by (Campbell, 2008; Flannery, n.d.; KirkPatrick, 2000). Rape is a stimulus that can elicits traumatic memories and emotional grief that goes to inhibit or cause dysfunction in pleasurable sexual expression in the victim's sex life (Tull, 2009). For example, a rape victim states that she has developed hatred for sex after she was raped as a young girl. To some extent, women who are exposed to rape have distorted cognitive perception of men as not genuine and unswerving companionable partners. The experience of rape dislocates the victim interpersonal relationship between them and men. Some even tend to hate men generally with unreserved resentment (Ellis, 2008; vanBerlon, Ensink, 2000). This was clearly, confirmed from the disclosure of a now married woman who was raped at the age of 13 years- "I lived with anger and bitterness towards everybody for 13 years until 2013 when I married. I hated men for many years, may be that was why I married at $28 "$.

The negative perception and cognition make it difficult for victims to cope with rape as they become helpless in the circumstances whereby, she will not get assistance from the justice system and their parents to punish the 
perpetrator. Consequently, it is evident from the narratives of the rape victims' cases reviewed in this paper that, women who experience sexual violence are susceptible to mental disorder and sexual dysfunction instantly or in later life. Common mental disorders rape victims are susceptible to includes posttraumatic stress disorder (PTSD) which is an extremely debilitating disorder whose symptoms occurs when an individual is exposed to an unpleasant traumatic event such as physical and sexual assault etc. Kirkpatrick (2000) reported that rape victims were 6.2 times more likely to develop PTSD than women who had never been victims of the crime (31\% vs 5\%). Therefore, one-third (31\%) of all rape victims develops posttraumatic stress in their lifetime (Kirkpatrick, 2000; National Centre for PTSD, n.d.). Of course, some women can recover to normal life after exposure to the trauma of rape experience in a short time. For example, Precious who was raped by her church friend recounted that she was emotionally brutalized by the so-called friend but had to let it go as a Christian (Punchonline newspaper, 2020).

Yet, some will have an enduring emotional stress reaction that could get worse over a long period of time. For women exposed to rape, the traumatized emotion can negatively interfere with their sexual life and social relationship due to feeling of paranoia and distrust of men (Tull, 2019; vanBerlon, Ensink, 2000). Survivors of sexual assault may develop PTSD for example, intrusion thought and experience of unpleasant memories related to the incidence may occur. This implies that they are always reliving the trauma and becoming upset when confronted with a traumatic reminder or thinking about a trauma evoking cue they noticed anywhere. Replaying these images, they might feel as though they are always in danger or need to always be on guard and may distrust other people (National Centre for PTSD, n.d; Tull, 2019). This was confirmed in the words of some rape victims - a Bauchi undergraduate student who was raped by her uncle she was staying with that "the experience has taught her lesson not to trust anyone because that person you trust might be the same person that will end up hurting you". Similarly, Sophia disclosed that she was raped by her uncle who was living with her family. After the incident, she added; "I was traumatized and scared of men. I use to fill with disgust, sometimes I felt nauseous and later to have nightmares".

Other victims also revealed that they had yet to heal from the grief of their being subjected to untold trauma for the bitter rape experiences (Punchonline newspaper, 2020). For example, Sylvia a raped during her first-year degree programme in 2005/2006 revealed that "it brought back memories; this is what I have live with every day and the memories are always new every time." Rachael another victim on her part revealed that "she still lives with scar to till today" (Punchonline newspaper, 2020). The second set of symptoms involves either staying away from places or people that remind you of the trauma, isolating from other people, or feeling numb, hyper-vigilant, irritable, or feeling easily startled (National Centre for PTSD, n.d.). In addition, PTSD may be complicated with depression disorder. For example, Kirkpatrick (2000) found that rape victims are three times more likely to suffer a major depression episode than non-victims (30\% vs 10). They are also 3.5 times more likely to be currently experiencing a major depression episode ( $21 \%$ vs $6 \%$ ). The suffering of depression disorder often triggers suicide thoughts and committing of suicide when they are feeling guilt by regretting and blaming self, feeling helpless, and worthless from the public ridicule and stigmatization of being raped.

Indeed, the burden of negative thoughts about rape such as stigmatization can lead to the victim feeling of low self-esteem. Victims of rape are duly exposed to stigma as a result of the societal perception and reaction towards the incidence of rape against the women. This is very common with families and the police who are expected to give 
maximum support and justice to the victim to ensure that perpetrator of the act is severely punished tend to trivialize and treat the victim's case with flippant attitude. In many cases, the victim is abused by the parents and exposed to mockery and blame by other people on the bases that she is the cause of her own experience of the incidence. When the story of a girl or woman raped becomes a topic of conversation in the community, her veritable qualities, character and self-respect diminishes. The emotional distress due to the perceived negative labelling, stigmatization and public ridicule precipitates the feeling of powerlessness, and self-worthlessness. According to Osman and Merwin (2019) this usually makes it easy to slip into a downward spiral of low self-esteem.

On the pedestrian social relationship, survivors of rape in many cases end up having interpersonal relationship problem as well as find it difficult to express and enjoy sexual intercourse all their life especially where they are not psychologically treated or not treated properly. This was evident in the case of rape victim Morenikea now married woman who was raped at the age of 13 years - "I lived with anger and bitterness towards everybody for 13 years until 2013 when I married. I hated men for many years, may be that was why I married at 28." The memories of rape are always there and anew every time as some victims reported. For, example, Rachael another victim of rape report that "after the incident, I was traumatize and became scared of men. I used to be filled with disgust, sometimes I felt nauseous and later began to have nightmare". This has agreed with the reports of studies that women with history of rape report worse social functioning than women without this history (Abdulrehman \& De Luca, 2001; Tong, Oates, \& McDwell, 1979) especially in intimate relationship (Tong, Oates, \& McDwell, 1979; Mullen, Martin, Anderson, \& Romans, 1994) cited in (Mohammed \& Hashish, 2019). Thus, victims like Morenike and Rachael as Osman and Merwin (2019) previously observed, these type of rape survivors can find it difficult to make or keep healthy relationships, if they are alone and unsupported by family and friends or spouse with an understanding, love and care.

The psychological impact of sexual violence particularly rape on the victim's sexual apathy and function is tremendous and can often cause a distressful misunderstanding and frustration in intimate relationship. This was established from a Nigerian table tennis player who bewails that "I have been abused and after beating me, he will forcefully have sex with me. It is when I grew up I got to know that it is called rape". As a result, she revealed that she has developed hatred for sex after she was raped as a young girl (Punch online Newspaper, 2020). Her negative emotion developed toward sex support previous research findings that females with histories of sexual violence are more likely to filter sexual experiences through negative self and sexual schemas, which in effect aroused experience of negative feelings such as guilt, regret, and disgust during sexual arousal (Schloredt, \& Heiman, 2003; Wenniger, \& Heiman, 1998) cited in (Mohammed \& Hashish, 2019). Moreover, Mohammed and Hashish (2019) have also proven that sexual dysfunction was evident in 33 out of 46 sexually active females who participated in their study $(65 \%)$. Therefore, as the severity of the sexual violence experience increased, the more the decrease in sexual function (Theilade, 2002; Gilmore, et al., 2010) cited in (Mohammed \& hashish, 2019).

Besides, given to their relative lack of social support, factors like intimacy and trust may take on additional meaning for women with history of sexual abuse, making these factors more important in determining how they affect sexual functioning (Mohammed \& Hashish, 2019). This is because women with a history of sexual abuse may exhibit unique cognitive and affective processes surrounding their sexuality (Mohammed \& hashish, 2019). As a 
result, women with a history of sexual abuse may lack a sense of ownership of their bodies, especially their sexual responses (Heiman, 2007) making physical aspects of sexual response less likely to strongly affect subjective wellbeing of one or the other (Mohammed \& Hashish, 2019). Certainly, most rape victims' sexual activity returned to normal but some have difficulties which persist over a long period of time (Ellis, 2008). They are emotionally blocked to experience the sensation of eroticism and sexual enjoyment. Some of the sexual dysfunction most survivors of sexual violence particularly rape experience includes loss of sexual arousal and desire inhibition, difficulty in reaching orgasm sexual avoidance contact, diminished satisfaction and pleasure in sexual activities (vanBerlo \& Ensink 2000; Ellis, 2008; Heiman, 2007). Some of the women become sexually frigid which makes them to feel pain and go cold in the process as a reaction from flashback to the rape experience during sexual intercourse.

\section{CONCLUSION}

Sexual violence against women is a sad reality in Nigeria and the occurrence of it has become a serious social health problem that has aroused a trumpeted public outcry and protest across the country. Of course, concerted efforts are made to curb this nuisance through government legislations that defined stiff punishment for anybody found guilty. Yet, hardly a day passes without a news report of sexual violence or assault on a woman-young and old. As a result of their exposure to sexual violence, these women suffered from severe psychological distress and psychosexual dysfunction as an aftermath effect. The disorders and sexual dysfunction of women with history of rape evident in the victims includes PTSD, sexual desire and arousal inhibition, sexual avoidance contact, anger and hatred, paranoia. Fear of relationship with men as well as stress and grief from the unpleasant memories of the rape incidence. Sadly, it is realized that most victim of sexual violence are left feeling physically brutalized and traumatized from a multiple trajectory bias of their powerlessness and marginalization in the society. Sexual violence can threaten the psychological wellbeing of the survivors in a short and long-term experience depending on the circumstances and probably where the victim is left without care and support from friends, family and appropriate professional intervention.

\section{RECOMMENDATIONS}

The study thus, recommends the following:

- Seeking and obtaining justice for a rape apparently may give relief and satisfaction to a victim feeling of humans and the law's respect for her right and equal opportunity to live in her environment without fear of molestation. However, this would not be enough to heal the social and emotional injury the woman with a history of rape sustained after the sexual assault. Hence, women who have being exposed to rape need intensive and proper psychological intervention to help them heal and develop resilience to cope with emotional trauma and the community stigmatization of her.

- Every government policy and programme to be designed for tackling sexual violence in the country must contain the psychological component for a holistic intervention. Consequently, experienced psychologists 
should always be involved in the development of any action plan during formation of committees, at the federal, state, local government, ministries, institutions and agencies for its development.

- In the course of seeking justice for gender-based violence cases, sentiments and emotions promoted by interested parties should be set aside. Each reported case must be left to be determined by its characteristics and validity through a legal process.

- Rape victims should be cared for and supported by her social network of family members, friends, professionals and the law enforcement agents.

\section{FUNDING}

This study was strictly funded from out-of-pocket finances.

\section{CONFLICT OF INTEREST}

The authors have no misunderstanding in the entire process and stages of writing and financing of the paper for publication.

\section{ACKNOWLEDGEMENT}

We like to appreciate the contribution of the media organizations for their role in the dissemination of information about sexual violence in Nigeria for purpose of drawing the government and other well-meaning Nigerian's attention to rise up and put heads together to control this human created public health challenge. We specially thank Ann Ameh the head of gender unit of the Criminal Investigation Department (CID) Benue state police command Makurdi for helping us with available statistics of sexual rape cases her unit has handle in the first half of the year 2020. 


\section{REFERENCES}

Adebajo, K. (2019). Fact Check: Are 2million Nigerian's women raped every year? Here is what we know. Retrieved from https://www.icirnigeria.com.

Agiriga, G. (2019). Epidemic of rape assailed in Nigeria| Voice of America- English Reprieved from voanews.com $>$ Africa

All Answers LTD. (November, 2018). Social and religious values behind Tiv traditional marriage. Retrieved from https://ukdiss,com/examples/tiv-traditional-marriage-values.php?vref=1

Ameh, A. (14 ${ }^{\text {th }}$ July, 2020). A one-on-one conversation. Gender Unit, Criminal investigation department (CID) Benue state police command, Makurdi.

Campbell, R. (2008). The psychological impact of rape victims. The American Psychologist. Vol. 63, DIO 10.10371003-066x.63.8.702

Carbon, S.B. (2012). An updated definition of rape. Department of Justice Archives. Retrieved from https: //www.justice.gov.

Editorial (18 ${ }^{\text {th }}$ June, 2020). Tackling Nigeria's rape crisis. Retrieved from https://www.Vanguardngr.com

Ellis, E.M. (2008). Sexual dysfunction in victims of rape. Women \& Health; vol. 5. 5:4, 35-48, DIO: 10.1300/j013v05n0404.

Flannery Jr, R.B. (n.d). Psychological Trauma and Posttraumatic Stress Disorder: Retrieved from https://www.ptsd.va.gov/public/pages/what-is-ptsd.asp

Heiman, J. (2007). Orgasmic disorder in women. In S. Leiblum (ed), Principles and practice of sex therapy. The Guildford Press, New York, pp. 84-123.

Jannike, L. (2019). Rape is prevalent in Nigeria, says report. Retrieved from https://www.vanguard.com.

KirkPatrick, D.G. (2000). Mental health impact of rape. Retrieved from https://www.mainweb-v.musc.edu

Madehin, T. (10 ${ }^{\text {th }}$ June, 2020). 75-years-oldman allegedly rapes teenager. Retrieved from https://t.co/WHuNwZjoFo

Madehin, T. (10 ${ }^{\text {th }}$ June, 2020). Police parade four suspected rapist, 32 others in Benue. Retrieved from https://t.co/PN04PJawn

Madehin, T. (10 ${ }^{\text {th }}$ June, 2020) 75-years-oldman allegedly rapes teenager. Retrieved from https://t.co/WHuNwZjoFo

Madehin, T. (20 th June, 2020). Police arrest teenagers for allegedly gang raping 15-years-old girl. Retrieved from https://t.co/7ox3Dp59OC

Madehin, T. $\left(26^{\text {th }}\right.$ June, 2020). Police arrest bishop for raping a 19years old girl in Delta state. Retrieved from https://t.co/DcukyoUR3k.

Madehin, T. (28 $8^{\text {th }}$ June, 2020). A pastor was arrested for purportedly raping a 16 years old girl. Retrieved from https://t.co/Zos7ZEsZna.

Mohammed, G.F., and \& Hashish, R.K.H (2015). Sexual violence against females and its impact on their sexual function. Egyptian Journal of Forensic Science; vol. 5. Issue 3

Moomoo, Q. (8 ${ }^{\text {th }}$ June, 2020). A man allegedly rapes 14years old girl in Kogi and threatens to kill family members. Retrieved from https://24report.com.ng 
Nnachi, E (29 ${ }^{\text {th }}$ July, 2020). I was repeatedly raped, forced to have sex with my brother. Retrieved form https://www.punchng.com

Odita, S. (29 $9^{\text {th }}$ July, 2020). How I was repeatedly raped, offered blood as water to drink by herders. Retrieved from https://www.m.guardian.ng

Olatunji, D. (30 $0^{\text {th }}$ July, 2020). Man, rapes 20years old girl with Down's syndrome. Retrieved form https://www.punchng.com

Punchonline newspaper $\left(6^{\text {th }}\right.$ June, 2020). Kogi commissioner for water resources vow not to resign in spite of investigation into the allegation of battery and rape levied against him. Retrieved form https://www.punchng.com

Punchonline newspaper ( $7^{\text {th }}$ June, 2020). The people of Benue state were embroiled by the death of Elizabeth Ogbaze after being repeatedly raped by a man and his son. Retrieved form https://www.punchng.com

Punchonline newspaper ( $8^{\text {th }}$ June, 2020). A 15-year-old boy arrested by police in Ekiti state for allegedly defiling a three-year old girl. Retrieved form https://www.punchng.com

Punchonline newspaper ( $9^{\text {th }}$ June, 2020). Member of House of Representatives placed a bounty of $\$ 150,000$ on a chieftain of All Progressive Grand Alliance (APGA) party for allegedly raping 15-year-olg girl, Retrieved form https://www.punchng.com

Punchonline newspaper (10 ${ }^{\text {th }}$ June, 2020). 35-year-old man nabbed for allegedly impregnating his stepdaughter. Retrieved form https://www.punchng.com

Punchonline newspaper (19 $9^{\text {th }}$ June, 2020). Police in Anambra state have arrested a 32-year-old man. Chigbo Akpulobo for allegedly defiling a seven-year-old girl. Retrieved form https://www.punchng.com

Punchonline newspaper $\left(20^{\text {th }}\right.$ June, 2020). Police arrest two teenagers for allegedly gang-raping 15-year- old girl. Retrieved form https://www.punchng.com

Punchonline newspaper (10 ${ }^{\text {th }}$ july, 2020). Motorcyclist 31 nabbed for raping 16-year-old girl at gunpoint. Retrieved form https://www.punchng.com

Ricardo, B., and Barker, G. (2008). Men, masculinities, sexual exploitation and sexual violence. Retrieved on March 26, 2020 from https://www,menegnage.org

Smuts, B. (1992). Male aggression against women: An evolutionary perspective. Human Nature, Vol. 3, No. 1, pp 1-44.

Tade, O., and Udechukwu, C. (2020). Characterizing rapists and their victims in selected Nigerian newspaper. Retrieved from DIO 105772/intechopen.91705. www.intechopen.com.

Tull, M. (28 ${ }^{\text {th }}$ September, 2019). Symptoms of PTSD after sexual assault. Retrieved from https://www.verywellmind.com

van Berlon, W., and Ensink, B. (2000). Problem with sexuality after sexual assault. Annu RevSex Res. Retrieved from PubMed.ncbi.nlm.nih.gov.

Women at Risk International Foundation (2020). Rape statistics in Nigeria. Retrieved from https://warifng.org

World Health Organization (n.d). Understanding and addressing violence against women. WHO_RHR_12.37_eng.pdf 